\title{
PENINGKATAN PRESTASI BELAJAR PENDIDIKAN AGAMA KATOLIK MELALUI METODE AMOS PADA PESERTA DIDIK SEKOLAH DASAR
}

\author{
Aurelius Fredimento ${ }^{1}$, Anselmus Mema ${ }^{2}$ \\ 1,2Program Studi PGSD Universitas Flores \\ 1betlehemk@gmail.com
}

\begin{abstract}
The first problem in the process of study of the Catholic Religion Education (PAK) at the Catholic Elementary School Of St. Antonius Ende 2 (SDK St. Antonius Ende 2) the achievement of study is not maximum yet. It is caused by the teacher who often uses communicative and assignment methods. These methods make the pupils feel bored follow the lesson. Besides that, there is still also another problem is the teacher of the PAK has less creativity to search, to find and to implement the model, and also alternative method that can make the pupils enjoy and glad to follow the lesson. To answer the situation, the method of amos can be used as an alternative study of PAK with the intention to increase the achievement of the pupils study of the PAK. The subject of the research are 22 pupils in the class IV of the SDK St. Antonius Ende 2. The data of the research is the result of the observation and the activities of the pupils and the last instrument test of every siclus. The data of the research, use qualitative descriptive. The result of the research by using the method of amos can increase the achievement of the pupils study in every siclus. In the prasiclus, the pupils who get thoroughness of study are $18,18 \%$, while the others who don't get completeness of study number $81,82 \%$. In the first siclus the pupils who get total are 94,46\%. And the other pupils who don't get completeness are 5,54\%. The second siclus, the pupils who get thoroughness are $100 \%$. Based on the results can be concluded that using the method of amos can increase the achievement of the pupils study in the class IV at SDK St. Antonius Ende 2.
\end{abstract}

Keywords: achievement of study; catholic religion education; contextual method; method of amos

\begin{abstract}
Abstrak
Permasalahan utama dalam proses pembelajaran Pendidikan Agama Katolik (PAK) di Sekolah Dasar Katolik St. Antonius Ende 2 (SDK St. Antonius Ende 2) adalah belum maksimalnya pencapaian prestasi belajar peserta didik. Hal ini disebabkan oleh guru PAK sering menggunakan ceramah dan penugasan. Dominasi penggunaan metode demikian, menimbulkan rasa bosan dan jenuh dari peserta didik dalam mengikuti pembelajaran. Permasalahan lainnya adalah minimnya kreativitas guru PAK dalam menemukan dan mengimplementasikan metode pembelajaran alternatif yang dapat memacu peserta didik mengikuti proses pembelajaran PAK. Menjawabi situasi demikian, metode amos dapat dijadikan sebagai metode alternatif pembelajaran PAK dengan tujuan untuk meningkatkan prestasi belajar peserta didik. Subjek penelitian dalam penelitian ini adalah peserta didik Kelas IV yang berjumlah 22 peserta didik. Data dalam penelitian ini diperoleh dari hasil pengamatan aktivitas peserta didik dan instrument tes akhir setiap siklus. Data penelitian ini dianalisis secara deskriptif kualitatif. Hasil penelitian menunjukkan bahwa penerapan metode amos dapat meningkatkan prestasi belajar peserta didik. Pada prasiklus peserta didik yang tuntas belajarnya mencapai $18,18 \%$ sedangkan yang tidak tuntas $81,82 \%$. Dalam siklus 1 peserta didik yang tuntas $94,46 \%$ dan yang belum tuntas adalah 5,54\%. Pada siklus 2, peserta didik yang tuntas mencapai 100\%. Berdasarkan hasil penelitian demikian, dapat disimpulkan bahwa penggunaan metode amos dapat meningkatkan prestasi belajar peserta didik Kelas IV SDK St. Antonius Ende 2.
\end{abstract}

Kata Kunci: metode amos; pendidikan agama katolik; prestasi belajar

\begin{tabular}{llll}
\hline Received & $: 2020-08-17$ & Approved & $: 2020-12-08$ \\
Reviesed & $: 2020-11-18$ & Published & $: 2021-01-31$ \\
\hline
\end{tabular}

Jurnal Cakrawala Pendas is licensed under a Creative Commons Attribution-

ShareAlike 4.0 International License. 


\section{Pendahuluan}

Pendidikan pada hakekatnya bertujuan untuk memanusiakan manusia dan mendatangkan perubahan yang berarti bagi masyarakat (Dewantara, 2018). Alasan mendasar dari dua pernyataan di atas adalah bahwa manusia itu senantiasa hidup dan terikat dalam suatu kelompok sosial masyarakat sehingga aktivitas mendidik manusia dengan sendirinya juga merupakan aktivitas mendidik terhadap masyarakat itu sendiri. Jika dalam satu kelompok masyarakat tidak dijumpai orang terdidik maka keterbelakanganlah yang akan menjadi warna khas masyarakat tersebut. Pendidikan berperan penting bagi perkembangan dan pembangunan sebuah bangsa. Semakin cerdas dan terdidik para warganya maka suatu bangsa dipastikan akan maju dan berkembang. Demikian pun sebaliknya, semakin kurang terdidik para warganya, suatu bangsa mengalami kehancuran (Purwanto, 2006; Irianto, 2017; Susilawati, 2020). Undang-Undang Dasar Negara Republik Indonesia Tahun 1945 (UUD Tahun 1945) dalam alinea keempat menegaskan salah satu fungsi dan tujuan pembangunan bangsa yakni mencerdaskan kehidupan bangsa. Fungsi dan tujuan ini, mendapat penegasanya kembali dalam Undang-Undang No. 20 Tahun 2003 tentang Sistem Pendidikan Nasional (UU Sikdiknas) yang dalam bab 2 pasal 3 menekankan bahwa "pendidikan nasional berfungsi dan bertujuan untuk mengembangkan kemampuan dan membentuk watak serta peradaban bangsa yang bermartabat dalam rangka mencerdaskan kehidupan bangsa, bertujuan untuk berkembangnya potensi peserta didik agar menjadi manusia yang beriman dan bertakwa kepada Tuhan Yang Maha Esa, berakhlak mulia, sehat, berilmu, cakap, kreatif, mandiri, dan menjadi warga negara yang demokratis serta bertanggung jawab".

Sekolah Dasar Katolik St. Antonius Ende 2 (SDK St. Antonius Ende 2) sebagai salah satu lembaga pendidikan yang bernafaskan Agama Katolik, dalam pengelolaan PAK, selain berdasarkan pada UUD 1945 dan UU Sikdinas, juga berpijak pada dokumen Gravissimum Educationis (GE) tentang Pendidikan Kristen yang menegaskan bahwa "Semua orang dari suku, kondisi atau usia manapun juga, berdasarkan martabat mereka selaku pribadi, mempunyai hak yang tak dapat diganggu-gugat atas pendidikan"(Konsili Vatikan, 1993). Hak dasar ini tak berhenti pada aspek transfer dan pencerapan ilmu pengetahuan namun bermuara pada pembinaan pribadi manusia yang serasih dan seimbang dalam perkembangan fisik, moral dan intelektual. Keserasihan dan keseimbangan perkembangan ketiga aspek ini, menjadi cikal bakal lahirnya pribadi-pribadi dewasa yang bertanggung jawab untuk kepentingan diri serta masyarakat di sekitarnya. Dalam dokumen ini, Gereja Katolik memberikan perhatian serius tentang pendidikan dalam hidup manusia serta dampaknya terhadap perkembangan masyarakat zaman sekarang. Pendidikan itu sesungguhnya hak semua orang dengan tujuan akhir yang mau di capai adalah (1) membangun kematangan hidup pribadi dalam terang kesempurnaan martabat ilahi mereka; (2) membangun dan menyalurkan kebaikan bagi masyarakat di mana mereka tinggal; (3) memampukan pribadi kristiani menyadari panggilannya dan (4) melatih diri untuk memberi kesaksian serta mendukung perubahan dunia menurut tata nilai kristiani (Konsili Vatikan, 1993; Yulis \& Goa, 2016).

$\mathrm{Ki}$ Hajar Dewantara menegaskan bahwa secara psikologis, pendidikan itu berhubungan dengan cipta, rasa dan karsa (Wardani, 2010; Hendratmoko et al., 2018) Cipta berkaitan dengan kemampuan daya pikir yang bertugas mencari kebenaran melalui pengalaman-pengalaman atau pengetahuan tentang yang benar dan yang salah. Rasa berkaitan dengan segala gerak gerik hati kita, senang atau susah, puas atau kecewa, benci atau cinta. Sedangkan karsa adalah kemauan yang merupakan hasil olahan yang sinergis antara pikiran dan perasaan. Ketiga hal ini merupakan syarat mutlak yang diperlukan manusia untuk mewujudkan dirinya sebagai manusia ideal, manusia yang diharapkan atau manusia yang dicita-citakan, yakni manusia yang tampilan sikap dan perilakunya, bersumber dari ajaran Tuhan melalui ajaran agama, bersumber dari budayanya serta bersumber dari diri manusia itu sendiri. Manusia dengan tampilan karater demikian, pada saatnya akan melahirkan pribadi manusia yang dewasa dan unggul dengan kualitas perkembangan fisik, moral dan intelektual yang dipertanggungjawabkan. 
Untuk mewujudkan tujuan pendidikan demikian, peran tri partit pendidikan sangat di butuhkan, yakni orangtua, sekolah dan masyarakat. Orangtua sebagai pendidik pertama dan utama sekaligus peletak dasar bagi keutamaan-keutamaan sosial sangat dibutuhkan anak. Keluarga merupakan faktor dominan dan terpenting dalam pendidikan nilai yang diawali dengan proses identifikasi, internalisasi dan panutan dan reproduksi langsung dari nilai-nilai moral yang hendak ditanamkan. Peran orangtua bagi pendidikan anak, yakni sebagai agen sosialisasi dalam memberikan dasar pendidikan, sikap dan keterampilan dasar, seperti agama, budi pekerti, sopan santun, estetika, kasih sayang dan rasa aman. Keutamaan-keutamaan sosial yang sudah ditanam dalam keluarga, mendapat kelanjutan pendidikannya dalam proses pendidikan di sekolah (Hendratmoko et al., 2018; Wuryandani, 2010).

Guru PAK di SDK St. Antonius Ende 2 juga menempati posisi sebagai pelanjut pendidikan yang sudah di mulai dalam keluarga. Guru PAK adalah seorang guru yang memberikan pendidikan Agama Katolik di sekolah-sekolah katolik. Untuk menjadi seorang guru PAK harus memiliki integritas kepribadian yang memadai yang dicirikan dengan memiliki kecerdasan, inovatif, kreatif, jujur, rendah hati, mandiri dan bertanggung jawab. Seorang guru PAK harus memiliki keseimbangan antara kualitas pengetahuan keagamaan Katolik dengan kualitas karakter dan keteladanan hidup yang mampu merangsang dan menggerakan peserta didik untuk membentuk dan menata hidup mereka sesuai dengan ajaran iman Katolik. Guru PAK melalui pendidikan, pengajaran dan keteladanannya, memberikan kontribusi yang besar bagi perubahan perilaku peserta didik ke arah yang positip sesuai dengan harapan agama dan bangsanya (Datus \& Wilhemus, 2018; Pranyoto, 2018).

Menjadi seorang guru PAK bukanlah perkara mudah karena tugas mendidik dan mengajar yang diembannya tidak hanya memacu peserta didik untuk tahu tentang inti ajaran Agama Katolik tetapi juga memiliki tanggung jawab dalam mendorong dan menuntun peserta didik agar mampu meresapi, menghayati dan mengamalkan inti ajaran Katolik dalam hidup praksis mereka sehari-hari (Prasetya, 2007; Tibo, P. 2017). Peran guru PAK menjadi penting dan mendesak karena ketika di kelas, mereka hadir sebagai pewarta keselamatan dan peyalur kehidupan Kristus kepada peserta didik demi mencapai kepenuhan hidup. Setiap langkah dan upaya guru PAK di kelas, mengarah pada satu titik capai yakni menggali pengalaman religius peserta didik sedini mungkin dengan harapan agar di kemudian hari mampu melahirkan peserta didik yang mengakui hidupnya sebagai pemberian Allah dalam balutan kesadaran sebagai makhluk yang terbatas dan tidak berdaya di hadapan yang ilahi (Iryanto \& Ardijanto, 2019; Daga, 2019).

Guru PAK dalam mentransfer dan menanamkan ajaran Katolik, harus memenuhi beberapa persyaratan yang sudah di gariskan secara tegas dalam Kitab Hukum Kanonik 1983. Dalam buku ketiga tentang tugas Gereja mengajar, khususnya kanon 804 dan 805 ditegaskan tentang wewenang dari otoritas Gereja atas pengajaran dan pendidikan Agama Katolik yang diberikan di sekolah-sekolah manapun atau diselenggarakan dengan pelbagai sarana komunikasi sosial. Wewenang mengajar Agama Katolik di berikan oleh ordinaris wilayah kepada guru-guru Agama Katolik yang unggul dalam ajaran yang benar, unggul dalam kesaksian hidup kristiani dan juga ahli dalam pendidikan. Dalam hal unggul dalam ajaran yang benar, Guru PAK harus memiliki kematangan intelektual yang handal karena tugasnya berkaitan dengan mengajar iman dan moral berdasarkan pada Kitab Suci dan Magisterium Gereja (Turu, 2019). Dalam hal unggul dalam kesaksian hidup, seorang guru PAK harus memiliki kematangan spiritual, afektif dan psikomotorik karena berkaitan dengan tugas mendidik dan menginternalisasikan iman dan moral berdasarkan Kitab Suci. Guru PAK harus meyakini diri dan keterpanggilannya sebagai murid Tuhan dengan menjalankan tugasnya secara bertanggung jawab melalui kesadaran iman sambil terus berusaha mendampingi peserta didik dengan nasehat-nasehat, sikap bersahabat serta contoh dan teladan hidup berdasarkan pada cinta dan kebaikan Kristus sendiri (Albert et al., 2018; Hamu, 2015). Sedangkan dalam hal ahli dalam pendidikan, seorang guru PAK harus membekali diri dengan ilmu keagamaan dan ilmu pengetahuan lainnya serta memiliki aneka kemahiran metode mendidik yang sesuai dengan penemuan-penemuan zaman modern. Ketiga hal ini 
menjadi atribut pendukung tercapainya misi pendidikan Agama Katolik yakni tegaknya Kerajaan Allah di dunia ini.

Sekolah Dasar Katolik St. Antonius Ende 2 (SDK St. Antonius Ende 2) sebagai salah satu lembaga pendidikan formil sekolah dasar, memiliki tanggung jawab untuk mengelolah pembelajaran PAK dengan baik demi meningkatkan prestasi belajar peserta didiknya. Namun, selama menjalani proses tersebut, banyak hambatan yang dialami, yakni minimnya upaya dan kreatifitas guru dalam mencari, menemukan dan menerapkan alternatif metode PAK yang kontekstual dan menyenangkan. Metode pembelajaran yang sering digunakan selama ini adalah metode pembelajaran klasik, yakni ceramah, diskusi dan tanya jawab yang terkadang kurang efektifif dan efisien bagi peserta didik dalam memahami dan menyerap konsep nilai-nilai keagamaan Katolik yang diajarkan. Hambatan lainnya yang dijumpai adalah guru PAK kurang menemukan dan memiliki langkah-langkah strategis dalam mengendalikan dan menguasai kelas sehingga proses pembelajarannya kurang berjalan dengan lancar sesuai dengan rancangan pembelajaran awal yang sudah disiapkan.

Berdasarkan pertimbangan demikian, peneliti menawarkan metode amos sebagai salah satu metode alternatif dalam pembelajaran PAK bagi peserta didik Kelas IV Sekolah Dasar Katolik St. Antonius Ende 2. Penamaan model ini berpijak dari refleksi atas karakteristik Nabi Amos sebagai pejuang keadilan dan kebenaran. Amos adalah seorang penggembala ternak dan pemungut buah ara hutan. Ia berasal dari Tekoa, sebuah dusun di wilayah Kerajaan Yehuda, dekat Betlehem, kurang lebih $9 \mathrm{~km}$ sebelah tenggara kota Yerusalem. Diilhami oleh Roh Allah menjadi nabi, ia kemudian melawan Raja Yeroboan II (783-743) dan diusir imam Bethel Amazia untuk kembali ke Yehuda (Habur, 2020). Metode amos adalah salah satu cara baru membaca Kitab Suci dengan beranjak dari realitas hidup di mana peserta didik berada, lalu membiarkan Firman Allah menerangi realitas tersebut. Dalam metode ini, peserta didik diajak untuk membaca dan memahami Firman Allah dengan bertolak dari situasi konkret dan pengalaman-pengalaman man riil yang peserta didik alami dan rasakan setiap hari. Situasi konkret dan masalah-masalah itu dianalisis dan dibedah dengan bantuan analisis sosial dengan tujuan untuk menemukan akar terdalam dari aneka masalah tersebut dan melatih peserta didik untuk menemukan apa kata Firman Allah terhadap masalah-masalah tersebut. Dalam proses pergumulan demikian, Firman Allah bisa saja hadir sebagai penerang, pemberi ilham, pendorong, pemberi kritik yang pedas dan tajam serta sebagai pembakar semangat atau spirit mereka dalam berjuang mengatasi persoalan tersebut.

Hal ini terasa penting dan mendesak sebagai bentuk penanaman awal nilai-nilai Alkitabiah kepada peserta didik sehingga pada saat dewasa ketika menemukan aneka masalah dalam hidup, mereka mampu menganalisa dan mengatasinya secara mandiri dan dewasa. Penerapan metode amos dalam pembelajaran PAK merupakan sebuah model pembentukan iman, harus menyentuh seluruh kepribadian peserta didik baik itu aspek kognitif, afektif dan psikomotorik. Sentuhan aspek kognitif itu, berhubungan dengan perolehan informasi yang benar tentang ajaran iman sehingga mampu melahirkan keyakinan iman. Sentuhan aspek afektif, berhubungan dengan penanaman semangat hidup doa, ibadat dan spiritualitas. Sedangkan sentuhan aspek psikomotorik, berhubungan dengan terlahirnya komitmen peserta didik untuk mencontohi sikap dan teladan Yesus dalam perbuatan nyata sehari (Habur, 2018; Setiyono \& Supriyadi, 2018)

Pelaksanaan metode amos pada pembelajaran PAK di SDK St. Antonius Ende 2 mengikuti prosedur-prosedur sebagai berikut: (1) melihat kenyataan hidup. Dalam langkah ini, guru PAK mengajak peserta didik melihat masalah sosial atau kasus-kasus konkret yang terjadi dalam konteks kehidupan peserta didik. Masalah sosial atau kasus konkret itu disajikan secara sederhana dalam bentuk narasi (ceritera), gambar, poster, foto ataupun video. Guru PAK sebagai fasilitator, berupaya mempertajam pemahaman peserta didik tentang tema tersebut melalui beberapa pertanyaan penelusuran terhadap ceritera, gambar, poster, foto ataupun video. Pertanyaan tersebut harus dikemas secara sederhana sesuai dengan daya tangkap peserta didik dengan tujuan membantu mereka mencari dan menemukan akar masalah dari masalah yang mereka alami; (2) mendengarkan Firman Allah. Dalam langkah 
ini, guru PAK menuntun peserta didik agar menjadikan Firman Allah sebagai sumber inspirasi dalam menerangi masalah tersebut sehingga bisa teratasi. Guru PAK sebagai fasilitator, berupaya mempertajam pemahaman peserta didik tentang inti Firman Allah melalui beberapa pertanyaan penelusuran terhadap Kitab Suci yang dibacakan. Pertanyaan itu harus dibuat secara sederhana sehinga memudahkan peserta didik menemukan keterkaitan antara amanat Kitab Suci dengan pengalaman hidupnya (3) merencanakan kegiatan. Guru PAK bersama peserta didik merencanakan bersama tindakan konkret sebagai jawaban atas amanat Firman Allah yang di dengarnya. Rencana tindakan yang direncanakan harus konkret dan riil serta mampu dilaksanakan entah secara pribadi ataupun kelompok dalam kekompakan dan persaudaraan kristiani (Habur, 2020; Tisera, 2002).

Penerapan metode amos dalam PAK di kelas secara praktis bertujuan untuk meningkatkan prestasi belajar peserta didik. Namun sampai saat ini, belum terlalu banyak dijumpai hasil penelitian terdahulu yang secara eksplisit berbicara tentang peran metode amos dalam proses pembelajaran PAK di kelas. Penelitian terdahulu yang sering dijumpai dan dapat dijadikan sebagai rujukan untuk mendukung penelitian ini, adalah hasil penelitian dengan variabel bebas penelitiannya bukan metode amos tetapi model pembelajaran kontekstual lainnya yang juga menekankan aspek konteks atau pengalaman peserta didik sebagai rujukan dasar dalam proses pembelajarannya. Penelitian terdahulu yang dapat dijadikan sebagai rujukan pendukung dalam penelitian ini adalah model pembelajaran Contextual Teaching and Learning (CTL) karena antara metode amos dengan model pembelajaran CTL memiliki kesamaan prinsip dan karakter, yakni membantu peserta didik memahami materi ajar dengan mengaitkannya pada situasi konkret dan pengalamanpengalaman iman riil sehingga peserta didik memiliki pengetahuan dan keterampilan yang dinamis, fleksibel dan otonom dalam mengonstruksi sendiri pemahamannya. Metode amos dan model pembelajaran CTL memberikan ruang bagi guru untuk mengaitkan antara materi yang diajarkannya dengan situasi dunia nyata peserta didik dan mendorong peserta didik membuat hubungan antara pengetahuan yang dimilikinya dengan penerapannya dalam kehidupan mereka sebagai anggota masyarakat (Agus, S. 2009; Dwi Kurino, Y. 2015; Adriyanti, W. 2016; Anjani, P.A., \& Putra, D.K.N.S. 2020). Yang sedikit membedakan metode amos dengan model pembelajaran CTL adalah dalam prosedur pembelajarannya, yang mana dalam metode amos, Kitab Suci mendapat posisi sentral dan menentukan sebagai dasar dan sumber inspirasi bagi peserta didik dalam menilai situasi konkret dan pengalamanpengalaman iman riil mereka demi terlahirlah sikap metanoia (pertobatan) menuju hidup baru sesuai dengan harapan Gereja. Pada moment ini, peserta didik dilatih untuk menempatkan situasi konkret dan pengalaman-pengalaman iman riil dalam sudut pandang Firman Allah demi terciptanya sebuah perubahan hidup ke arah yang lebih baik dan matang sesuai dengan Kehendak Allah dalam Kitab Suci.

Berikut ini dikemukakan beberapa penelitian terdahulu yang menggunakan model CTL dalam pembelajaran agama, yakni: (1)Sitindaon (2018) dalam penelitiannya membuktikan bahwa penggunaan model CTL dapat meningkatkan hasil belajar siswa Kelas VIII SMP Negeri 2 Babalan Tahun Pelajaran 2018-2019 pada mata pelajaran Pendidikan Agama Islam; (2)Taufik (2019) dalam penelitiannya, juga membuktikan bahwa model pembelajaran CTL juga dapat meningkatkan hasil belajar siswa Kelas XI Adminitrasi 3 Sekolah Menengah Kejuruan (SMK) Negeri 1 Palopo tahun ajaran 2018/2019 pada mata pelajaran Agama Islam; (3) Humaya, M. (2019) dalam penelitiannya membuktikan bahwa CTL mampu meningkatkan hasil belajar siswa kelas VI SD Negeri 212 Bontobangun Kabupaten Bulukumba; (4)Menaka, I..N., \& Yogantara, I.W.L (2020) dalam kesimpulan akhirnya dari penelitiannya menegaskan bahwa penerapan model pembelajaran CTL dapat meningkatkan hasil belajar Pendidikan Agama Hindu dan Budi Pekerti Pada Siswa Kelas X.IBB.1 SMA Negeri 1 Bebandem Tahun Pelajaran 2018/2019 dan (5)Hyun et al., (2020) dalam penelitiannya membuktikan bahwa model CTL menjadi tindakan yang paling tepat untuk meningkatkan konsep dan praktik cinta dalam Integrasi Belajar-Keyakinan bagi peserta sekolah minggu Yeollin.

Hasil penelitian dari beberapa penelitian terdahulu ini secara implisit menegaskan 
sekaligus memberikan keyakinan kepada guru PAK dalam jenjang pendidikan apapun bahwa penggunaan metode kontekstual (metode amos) dalam pembelajaran PAK dapat memberikan kontribusi yang signifikan bagi peningkatan prestasi belajar peserta didik. Oleh karena itu, para guru PAK dalam setiap rancangan dan implementasi pembelajaran PAK di kelas, dapat menggunakan metode kontekstual sambil tetap berupaya mempertahankan perannya sebagai fasilitator yang menghargai potensi dan kemampuan peserta didik sambil berusaha semaksimal mungkin menjauhkan diri dari pola pendekatan otoriter demi pemaksimalan perkembangan ide-ide, teori-teori, atau cita-cita yang bermakna bagi suatu kemajuan perkembangan pendidikan di Indonesia yang lebih berkualitas sehinga mampu mewujudkan cita-cita pembangunan Indonesia, yakni mencerdaskan kehidupan bangsa (Gandhi, H. W., \& Wangsa, T. 2011; Yunus, 2016; Fadlillah, 2017)

\section{Metode Penelitian}

Jenis penelitian ini berfokus pada upaya guru PAK dalam meningkatkan prestasi belajar peserta didik Kelas IV SDK. St. Antonius Ende 2 melalui penerapan metode amos. Jenis penelitian yang digunakan adalah penelitian kualitatif yang menggunakan pendekatan deduktif induktif, berangkat dari suatu kerangka teori, gagasan para ahli ataupun pemahaman peneliti selanjutnya dikembangkan menjadi permasalahan beserta pemecahannya dalam bentuk dukungan data empiris di lapangan. Metode penelitian yang digunakan dalam penelitian ini adalah metode PTK (Classroom Action Researc). Metode PTK adalah sebuah kegiatan penelitian yang dilakukan di kelasnya sendiri dengan jalan merancang, melaksanakan, mengamati dan merefleksikan tindakan melalui beberapa siklus secara kolaboratif dan partisipatif yang bertujuan untuk memperbaiki atau meningkatkan mutu proses pembelajaran di kelasnya (Kunandar, 2007).

Penelitian Tindakan Kelas (PTK) secara praktisnya berisikan kajian sistematik dari upaya perbaikan pelaksanaan praktik pendidikan oleh sekelompok guru dengan melakukan tindakan-tindakan dalam pembelajaran berdasarkan refleksi mereka atas hasil dari tindakantindakan tersebut. Model yang dipakai dalam PTK ini adalah model Kemmis \& Taggart yang dalam pelaksanaannya mengikuti tahapan-tahapan sebagai berikut: (1) perencanaan, (2) pelaksanaan, (3) pengamatan, dan (4) refleksi (Hanifah, 2014; Sanjaya, 2016). Sedangkan teknik pengumpulan data yang digunakan adalah teknik observasi, wawancara, kuesioner, dokumentasi serta tes. Instrumen pengumpulan data dalam penelitian ini berupa soal tes pilihan ganda dan esay tes. Hasil tes peserta didik setiap akhir siklus diolah dengan cara memberikan skor pada masing-masing butir soal. Setiap butir soal diberi bobot berdasarkan tingkat kesulitannya. Setelah mendapat skor prestasi belajar, kemudian di kategorikan ke dalam ketuntatasan belajar yang di dasarkan pada Kriteria Ketuntasan Belajar Minimal (KKBM) di SDK St. Antonius Ende 2 untuk mata pelajaran PAK, yakni 70. Semua data penelitian ini dianalisis secara deskriptif kualitatif (Supardi \& Suharsimi, 2009). Penelitian ini dilaksanakan sejak tanggal 31 Oktober 2019 sampai dengan tanggal 14 Nopember 2019 dengan subjek penelitiannya adalah peserta didik Kelas IV SDK. St. Antonius 2 yang berjumlah 22 peserta didik.

\section{Hasil dan Pembahasan}

Penelitian Tindakan Kelas (PTK) ini dilaksanakan dalam dua (2) siklus. Siklus pertama dilaksanakan pada hari Kamis, 31 Oktober 2019 di SDK St. Antonius Ende 2. Sebelum melaksanakan siklus pertama, peneliti melakukan kegiatan pra tindakan. Dalam kegiatan ini, guru menjelaskan materi hormat kepada orangtua kepada peserta didik Kelas IV SDK St. Antonius Ende 2 dengan menggunakan metode ceramah. Akhir dari penjelasan, guru membagikan lembaran soal pre test kepada peserta didik untuk dikerjakan selama 30 menit. 
Jenis soal pre test yang dipilih adalah jenis pilihan ganda dengan jumlah 15 soal. Pengerjaan soal pre test ini bertujuan untuk mengetahui sejauh mana pengetahuan dasar peserta didik tentang materi hormat kepada orangtua sebelum metode amos diterapkan. Setelah memeriksa lembaran jawab pretest peserta didik, pencapai ketuntatasan belajar peserta didik ditampilkan dalam gambar 1 berikut ini:

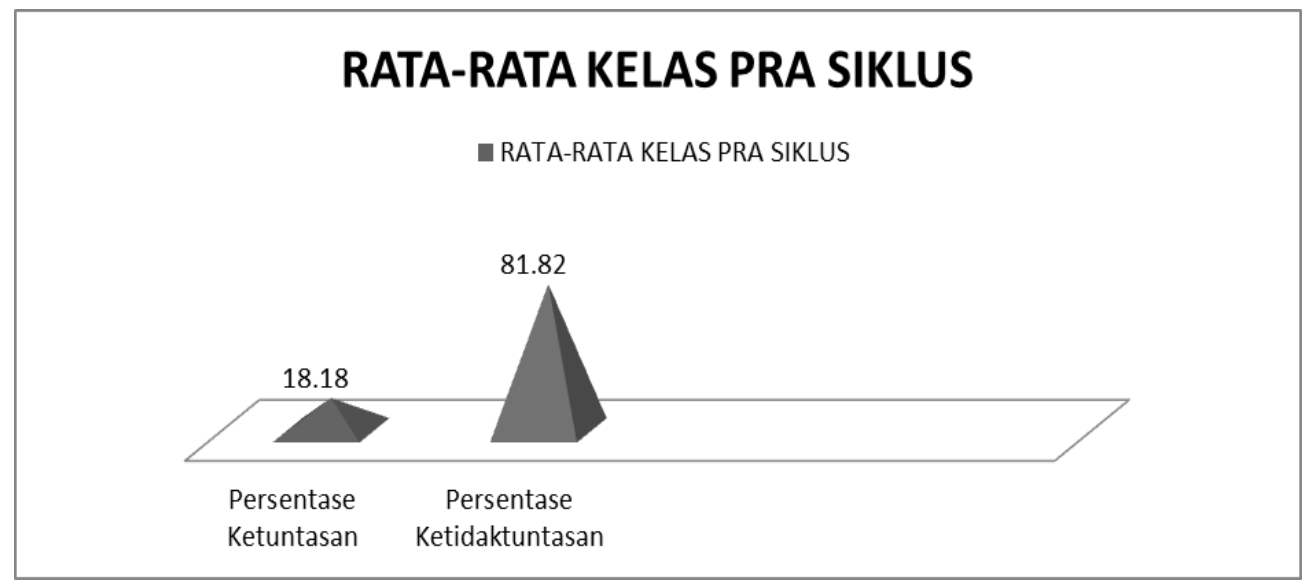

Gambar 1. Diagram Kondisi Riil Pencapaian Prestasi Belajar Fase Pretest

Berdasarkan gambar 1 di atas, diketahui bahwa hanya $18,18 \%$ atau sekitar 4 peserta didik yang mencapai ketuntasan belajar. Sedangkan persentase ketidaktuntasan peserta didik mencapai $81,82 \%$ atau 18 peserta didik. Pencapaian persentase ketuntasan belajar peserta didik pada fase pretest yang kurang memuaskan ini, mendorong peneliti melakukan refleksi dan analisis untuk mengetahui akar permasalahannya, yakni pembelajaran PAK pada fase pretest tidak disertai dengan penggunaan media pembelajaran yang menarik. Oleh karena itu, pada siklus 1 bagian langkah pertama: melihat situasi hidup, peneliti menyisipkannya dengan pemutaran sebuah video yang berjudul maling kundang. Pemutaran video ini, mampu menghidupkan suasana pembelajaran karena peserta didik menunjukkan keaktifan dalam menjawab setiap pertanyaan guru dan peserta didik lainnya. Untuk membuktikan efektivitas penerapan media video terhadap peningkatan prestasi belajar peserta didik, peneliti membagikan lembaran soal post test siklus 1 (15 soal pilihan ganda dan 5 soal isian) kepada peserta didik untuk di kerjakan. Berikut ini ditampilkan kondisi riil pencapaian prestasi belajar pada siklus 1 dalam bentuk diagram berikut ini:

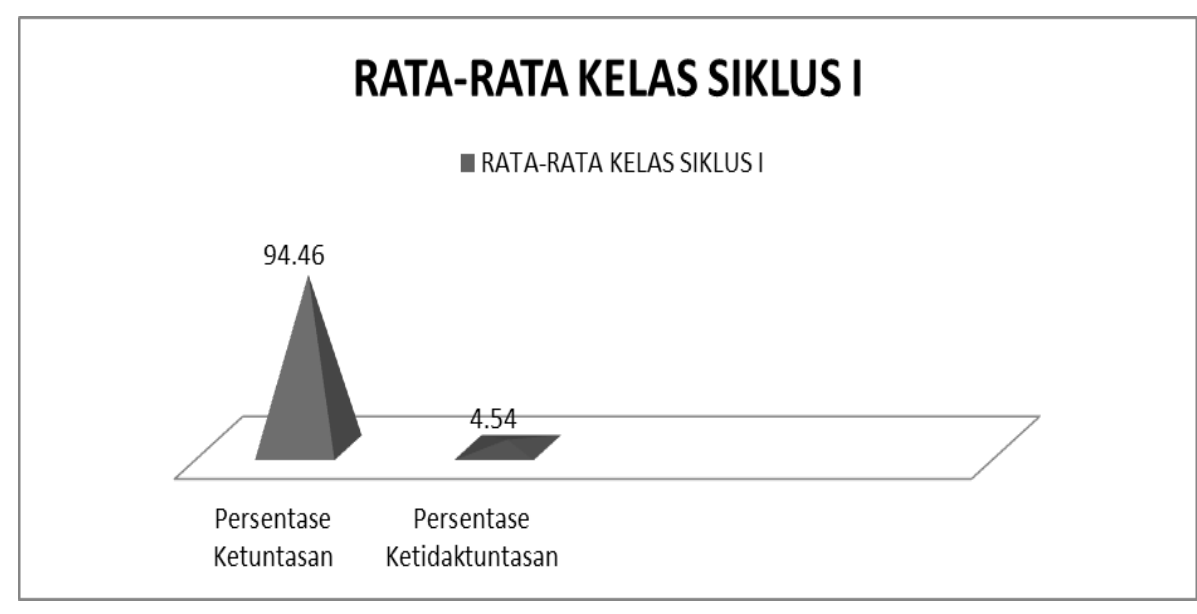

Gambar 2. Diagram Kondisi Riil Pencapaian Prestasi Belajar Siklus 1

Gambar 2 di atas menunjukkan bahwa persentase ketuntasan belajar peserta didik pada siklus 1 mengalami peningkatan. Dari fase pre test hanya 4 peserta didik atau sekitar $18,18 \%$ yang mencapai ketuntatasan belajar; pada post test siklus 1 mengalami peningkatan menjadi 21 peserta didik atau sekitar 95,45\% yang mencapai ketuntasan belajar. Sedangkan persentase 
ketidaktuntatasan pada fase pre test yang mencapai 18 peserta didik atau $81,82 \%$, pada post test siklus 1 mengalami penurunan menjadi 1 peserta didik atau 4,54\% yang tidak mencapai ketuntasan. Penerapan metode amos dalam PAK di siklus 1 sudah menunjukkan kontribusinya yang positip bagi peningkatan prestasi belajar peserta didik. Meski demikian, dalam siklus 1, masih dijumpai beberapa hambatan riil yang dialami oleh peserta didik, yakni: (1) proses pengerjaan Lembaran Kerja Siswa (LKS) oleh peserta didik sedikit tidak sesuai dengan alokasi waktu yang disiapkan karena rangkaian bahasa dalam LKS tidak menjangkau kemampuan cerna peserta didik; (2) selama proses pembelajaran berlangsung, dijumpai sebagian peserta didik yang kurang serius mengikuti proses pembelajaran sehingga peneliti harus menyiapkan tambahan waktu yang cukup untuk menenangkan mereka; (3) masih dijumpai seorang peserta didik yang kemampuan kognitifnya berada di bawah rata-rata; (4) peserta didik mayoritas tidak membawa Alkitab sehingga menghambat kelancaran proses pelaksanaan metode amos khususnya pada langkah ketiga mendengarkan Firman Allah.

Pelaksanaan siklus 2 dilaksanakan pada hari Kamis, 14 Nopember 2019 dengan tetap mengikuti tahapan-tahapan metode amos sambil memperhatikan beberapa perbaikan dan catatan yang didapat dari siklus 1, yakni: (1) semua suruhan dalam LKS disusun kembali dalam bahasa yang sederhana sehingga bisa dipahami oleh peserta didik; (2) untuk menenangkan peserta didik dalam siklus 2, pada langkah mendalami situasi hidup, peneliti tidak lagi memutarkan video tetapi menggantikannya dengan membagikan sebuah ceritera yang berjudul: batu menangis; (3) memberikan pendampingan khusus pada seorang peserta didik yang kemampuan kognitifnya berada di bawah rata-rata; (4) menyiapkan Alkitab untuk peserta didik yang lupa membawanya. Akhir dari proses ini, peneliti membagikan lembaran soal pos test siklus 2 ( 15 soal pilihan ganda dan 5 soal isian). Suasana ketenangan dalam mengerjakan soal tetap diupayakan oleh guru sehingga peserta didik dapat mengerjakan soal post test siklus 2 dengan baik. Setelah memeriksa semua lembaran jawaban, berikut ini ditampilkan kondisi riil pencapaian prestasi belajar peserta didik pada siklus 2, yakni:

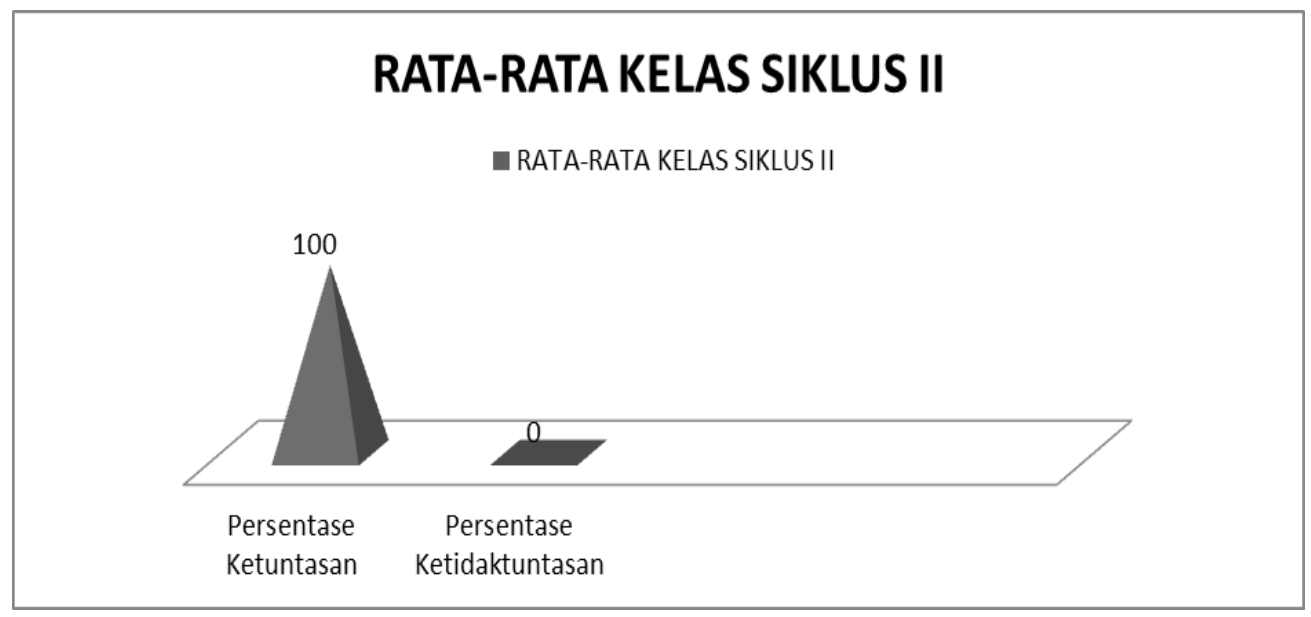

Gambar 3. Diagram Kondisi Riil Pencapaian Prestasi Belajar Siklus II

Gambar 3 di atas menunjukkan bahwa pembelajaran PAK yang bertolak dari situasi konkret dan pengalaman-pengalaman iman riil yang peserta didik alami dan rasakan setiap hari dapat mempengaruhi peningkatan prestasi belajar yang maksimal. Hal ini dibuktikan dengan perkembangan persentase ketuntasan belajar peserta didik pada pra siklus hanya mencapai $18,18 \%$ tetapi mengalami peningkatan $77,28 \%$ pada siklus 1 sehingga menjadi 95,46\%. Pada siklus 2 mengalami lagi peningkatan 4,54\% sehingga mencapai $100 \%$.

Peningkatan prestasi belajar melalui metode amos ini, secara implisit sudah dibuktikan oleh penelitian-penelitian terdahulu. Dalam penelitian-penelitian itu, telah dibuktikan bahwa penggunaan model CTL dalam pembelajaran agama, dapat meningkatkan hasil belajar peserta didik. Berikut ini akan ditampilkan hasil penelitian dari penelitianpenelitian terdahulu, yakni: (1)Sitindaon (2018) dalam penelitiannya membuktikan bahwa 
penggunaan model CTL dapat meningkatkan hasil belajar siswa Kelas VIII SMP Negeri 2 Babalan Tahun Pelajaran 2018-2019 pada mata pelajaran Pendidikan Agama Islam. Hal ini dapat dilihat dari perolehan niai rata-rata pada pra-Siklus sebesar 66,3 (37\%), pada Siklus I mencapai 75,8 (68\%) dan pada Siklus II meningkat menjadi 82,1 (84\%); (2)Taufik (2019) dalam penelitiannya, juga membuktikan bahwa model pembelajaran CTL juga dapat meningkatkan hasil belajar siswa Kelas XI Adminitrasi 3 Sekolah Menengah Kejuruan (SMK) Negeri 1 Palopo tahun ajaran 2018/2019 pada mata pelajaran Agama Islam. Hasil penelitiannya menunjukkan pada saat dilakukan tes akhir Siklus I hasil materi belajar siswa sebesar $73.52 \%$, selanjutnya pada siklus II terdapat peningkatan hasil materi belajar siwa sebesar $81.48 \%$ atau sekitar 7,91\% pada ranah aspek kognitif, afektif, dan psikomotorik; (3) Humaya, M. (2019) dalam penelitiannya membuktikan bahwa CTL meningkatkan hasil belajar siswa kelas VI SD Negeri 212 Bontobangun Kabupaten Bulukumba. Peningkatan persentase hasil belajar murid yang tuntas dari 36,36\% menjadi 90,91\%; (4)Menaka, I..N., \& Yogantara, I.W.L (2020) dalam kesimpulan akhirnya dari penelitiannya menegaskan bahwa penerapan model pembelajaran CTL dapat meningkatkan hasil belajar Pendidikan Agama Hindu dan Budi Pekerti Pada Siswa Kelas X.IBB.1 SMA Negeri 1 Bebandem Tahun Pelajaran 2018/2019 dan (5) Hyun et al., (2020) dalam penelitiannya membuktikan bahwa model CTL terbukti menjadi tindakan yang paling tepat untuk meningkatkan konsep dan praktik cinta dalam Integrasi Belajar-Keyakinan bagi peserta sekolah minggu Yeollin di Korea. Berdasarkan hasil perkembangan concept of love terus meningkat $(34 \% \rightarrow 55 \%$-> $79 \%)$ dan perkembangan practice of love-1 naik turun $(34 \%->100 \%->89 \%)$ dan practice of love-2 naik dan berhenti ( $0 \%$-> 78\% -> 78\%). (Sitindaon, n.d.)

Merujuk pada hasil penelitian penerapan metode amos dan beberapa penelitian terdahulu, dapat ditegaskan bahwa penggunaan metode amos dalam PAK di kelas dapat dijadikan sebagai salah satu metode alternatif pembelajaran PAK di kelas karena mampu meningkatkan prestasi belajar dan hasil belajar peserta didik. Metode amos ini merupakan salah cara baru membaca Kitab Suci yang digunakan guru dalam pembelajaran PAK dengan tujuan untuk menanamkan kualitas keimanan dan ketakwaan peserta didik pada Allah melalui proses pergumulan yang panjang atas situasi konkret dan pengalaman-pengalaman iman peserta didik setiap hari. Penanaman dan penguatan iman yang bersumber dari situasi konkret dan pengalaman-pengalaman iman riil peserta didik, diharapkan bisa melahirkan sebuah generasi bangsa masa depan yang senantiasa optimis dalam menghadapi setiap persoalan dan dinamika hidup yang mereka alami karena selalu menyakininya sebagai sebuah bentuk rencana Allah yang tersembunyi untuk diri dan hidup mereka.

Berdasarkan pencapaian ketuntatasan belajar peserta didik dari fase pre test, pos test siklus 1 dan pos test siklus 2; berikut ini akan ditampilkan diagram perbandingan persentase ketuntatasan belajar peserta didik, yakni:

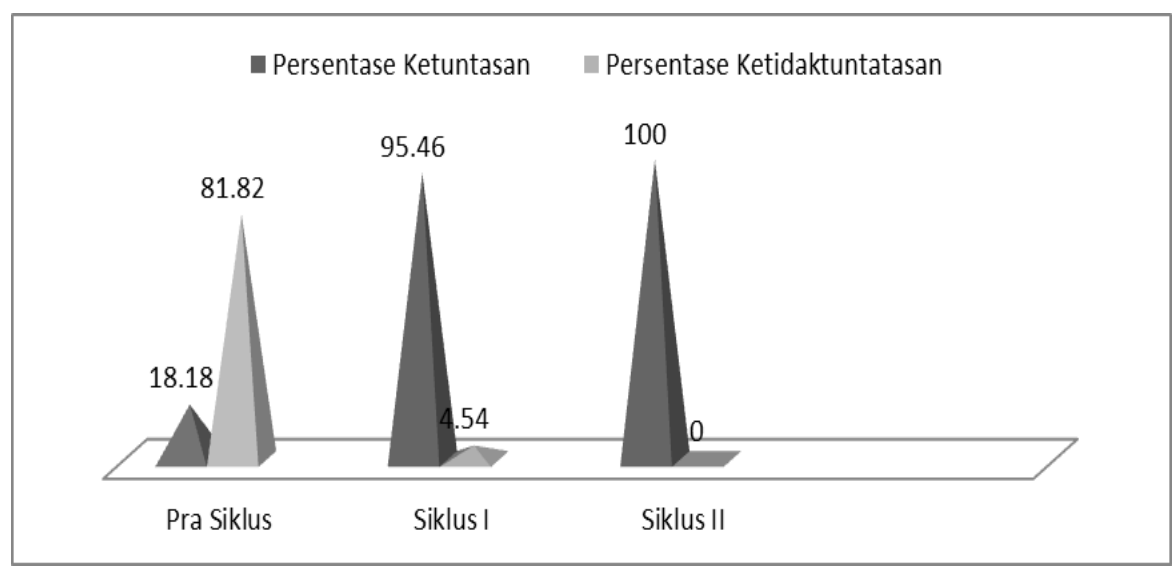

Gambar 4. Diagram Perbandingan Persentase Ketuntasan Belajar Prasiklus, Siklus 1 dan Siklus 2

Berdasarkan gambar 4 di atas, tampak dengan jelas bahwa penggunaan metode amos setiap siklus dengan memperhatikan beberapa penyempurnaannya, dapat meningkatkan 
prestasi belajar peserta didik pada pembelajaran PAK di SDK St. Antonius Ende 2. Persentase ketuntasan belajar peserta didik pada pra siklus hanya mencapai 18,18\%. Tetapi pada siklus 1 sudah mengalami peningkatan $77,28 \%$ sehingga menjadi $95,46 \%$. Pada siklus 2 , mengalami lagi peningkatan 4,54\% sehingga menjadi $100 \%$.

\section{Kesimpulan}

Berdasarkan hasil penelitian dari penerapan metode amos terhadap mata pelajaran PAK Kelas IV materi hormat kepada orangtua di SDK St. Antonius Ende 2, maka disimpulkan bahwa penerapan metode amos dalam pembelajaran PAK dapat meningkatkan prestasi belajar peserta didik. Hal ini dapat dilihat pada pencapaian ketuntatasan belajar peserta didik dari semua siklus. Pada pra siklus persentase ketuntasan belajar peserta didik hanya $18,18 \%$. Namun pada siklus 1 persentase ketuntasan belajar peserta didik mencapai 95,46\% berarti mengalami peningkatan sebesar 4,54\% dari pencapaian ketuntatasan belajar pada siklus 1 . Berdasarkan hasil penelitian ini, maka diharapkan agar semua guru PAK dalam jenjang pendidikan sekola dasar, jenjang pendidikan pendidikan sekolah menengah pertama dan jenjang pendidikan sekolah menengah atas, dapat menjadikan metode amos ini sebagai salah satu metode alternatif dalam pembelajaran PAK demi meningkat prestasi belajar peserta didik.

\section{Daftar Pustaka}

Agus, S. (2009). Cooperative Learning Teori dan Aplikasi Paikem. Yogyakarta: Pustaka Pelajar.

Andriyanti, W. (2016). Model Pembelajaran Contextual Teaching And Learning dalam Pembelajaran Menulis Permulaan di Kelas II Sekolah Dasar. Jurnal Cakrawala Pendas, 2 (2).

Anjani, P. A., \& Putra, D. K. N. S. (2020). Pengaruh Model Pembelajaran Contextual Teaching and Learning Berbantuan Media Konkret Terhadap Kompetensi Pengetahuan IPA. Journal for Lesson and Learning Studies, 3(2), 230-237.

Daga, A. T. (2019). Relevansi Kurikulum Mata Kuliah Pendidikan Agama Katolik Dalam Mengembangkan Karakter Mahasiswa. JUMPA: Jurnal Masalah Pastoral, 7 (1), 13 13.

Datus, K., \& Wilhemus, O. R. (2018). Peranan Guru Agama Katolik Dalam Meningkatkan Mutu Dan Penghayatan Iman Siswa Sekolah Menengah Tingkat Atas Kota Madiun Melalui Pengajaran Agama Katolik. JPAK: Jurnal Pendidikan Agama Katolik, 20 (10), 144-166.

Dewantara, A. (2018). Filosofi Pendidikan Katolik dalam Perspektif Filsafat Aristotelian. JPAK: Jurnal Pendidikan Agama Katolik, 12 (6).

Dwi Kurino, Y. (2015). Pengaruh Contextual Teaching \& Learning dan Direct Intruction terhadap Peningkatan Kemampuan Pemahaman Matematis Siswa SD. Jurnal Cakrawala Pendas, 1 (1).

Fadlillah, M. (2017). Aliran Progresivisme Dalam Pendidikan Di Indonesia. Jurnal Dimensi Pendidikan Dan Pembelajaran, 5 (1), 17-24. http://journal.umpo.ac.id/index.php/dimensi/article/view/322

Gandhi, H. W., \& Wangsa, T. (2011). Filsafat Pendidikan: Mazhab-Mazhab Filsafat Pendidikan. Yogyakarta: Ar-Ruzz Media.

Habur, A. M. (2018). Pendekatan Holistik Dalam Katekese Kontekstual Gereja Lokal Manggarai. In Widyawati (Eds.) Gereja Pewarta, 68. Ruteng: STKIP St. Paulus.

Habur, A. M. (2020). Diakonia Jantung Katekese. In Martin Chen \& Agustinus Manfred Habur (Eds.) Diakonia Gereja, 113. Jakarta: Obor.

Hamu, F. J. (2015). Kompetensi Guru Agama Katolik. SEPAKAT: Jurnal Pastoral Kateketik, 
$1(1), 10-19$.

Hanifah, N. (2014). Memahami Penelitian Tindakan Kelas: Teori dan Aplikasinya. Bandung: UPI Press.

Hendratmoko, T., Kuswandi, D., \& Setyosari, P. (2018). Tujuan Pembelajaran Berlandaskan Konsep Pendidikan Jiwa Merdeka Ki Hajar Dewantara. JINOTEP (Jurnal Inovasi Dan Teknologi Pembelajaran): Kajian Dan Riset Dalam Teknologi Pembelajaran, 3 (2), 152-157.

Humaya, M. (2019). Penerapan Contextual Teaching and Learning untuk Meningkatkan Hasil Belajar Pendidikan Agama Islam pada Materi Hari Akhir di Kelas VI SD Negeri 212 Bontobangun Kabupaten Bulukumba. Jurnal Pemikiran dan Pengembangan Pembelajaran, 1 (1), 87-92.

Hyun, C. C., Wijayanti, L. M., Asbari, M., Purwanto, A., Santoso, P. B., Igak, W., Bernarto, I., \& Pramono, R. (2020). Implementation of Contextual Teaching and Learning (CTL) to Improve the Concept and Practice of Love for Faith-Learning Integration. International Journal of Control and Automation, 13 (1), 365-383.

Indonesia, R. (2002). Undang-Undang Dasar Negara Republik Indonesia Tahun 1945. Sekretariat Jenderal MPR RI.

Irianto, H. A. (2017). Pendidikan Sebagai Investasi Dalam Pembangunan Suatu Bangsa. Jakarta: Kencana.

Iryanto, A., \& Ardijanto, D. B. K. (2019). Pemahaman Guru Pendidikan Agama Katolik Tentang Tugas Misioner Gereja Dan Pelaksanaannya Di SLTA Katolik Kota Madiun. JPAK: Jurnal Pendidikan Agama Katolik, 19 (1), 100-115. https://doi.org/10.34150/jpak.v19i1.171.

Kementerian Pendidikan Dan Kebudayaan (2017). Pendidikan Agama Katolik Dan Budi Pekerti. Jakarta: Kementerian Pendidikan Dan Kebudayaan.

Konferensi Waligereja Indonesia (2006). Kitab Hukum Kanonik. Jakarta: Obor.

Konsili Vatikan, II. (1993). Dokumen Konsili Vatikan II. R. Hardawiryana, (Penerjemah). Jakarta: Obor. (Dokumen Asli Diterbitkan Tahun 1966).

Kunandar, D. R. (2007). Langkah Mudah Penelitian Tindakan Kelas Sebagai Pengembangan Guru Profesional. Jakarta: Rajawali Pers.

Menaka, I. N., \& Yogantara, I. W. L. (2020). Penerapan Model Pembelajaran Contextual Teaching And Learning (CTL) Untuk Meningkatkan Hasil Belajar Pendidikan Agama Hindu Dan Budi Pekerti Pada Siswa Kelas X. IBB. 1 SMA Negeri 1 Bebandem Tahun Pelajaran 2018/2019. SANG ACHARYA: Jurnal Profesi Guru, 1 (2), 50-54.

Pranyoto, Y. H. (2018). Revitalisasi Pendidikan Agama Katolik Di Sekolah Sebagai Upaya Meningkatkan Moralitas Anak Didik. JUMPA: Jurnal Masalah Pastoral, 6 (2), 19-19.

Prasetya, L. (2007). Karya Pengembalaan Dewan Paroki. Yogyakarta: Kanisius.

Purwanto, N. A. (2006). Kontribusi Pendidikan Bagi Pembangunan Ekonomi Negara. Jurnal Manajemen Pendidikan UNY, 114456, 02 (2), 1-7.

Sanjaya, D. R. H. W. (2016). Penelitian Tindakan Kelas. Jakarta: Prenada Media.

Setiyono, S. D., \& Supriyadi, A. (2018). Katekese Kontekstual: Sarana Dalam Membangun Gereja Sebagai Umat Allah Di Paroki St. Hilarius Klepu. JPAK: Jurnal Pendidikan Agama Katolik, 20 (10), 42-56.

Sitindaon, R. R. (2018). Peningkatan Hasil Belajar Dan Aktivitas Belajar Pendidikan Agama Kristen Melalui Model Pembelajaran Contextual Teaching And Learning Siswa Kelas VIII SMP Negeri 2 Babalan Tahun Pelajaran 2018-2019. TABULARASA: 15 (3), 369-379.

Supardi, S., \& Suharsimi, A. (2009). Penelitian Tindakan Kelas. Jakarta: Bumi Aksara.

Taufik, I. (2019). Penerapan Model Pembelajaran Contextual Teaching And Learning (CTL) Dalam Meningkatkan Hasil Belajar. IQRO: Journal of Islamic Education, 2 (2), 163174.

Tibo, P. (2017). Pengembangan Belajar Mengajar Pendidikan Agama Katolik Yang Kontekstual Di Sekolah Menengah Pertama Swasta Katolik Kevikepan Ende. JUMPA: Jurnal Masalah Pastoral, 5 (1), 18-18. 
Tisera, G. (2002). Syering Kitab Suci. Maumere: Lembaga Pembentukan Berlanjut Arnold Janssen (LPBAJ).

Turu, D. W. S. (2019). Peningkatan Kualitas Guru Pendidikan Agama Katolik (PAK) Melalui Penerapan Model Rekrutmen Dan Seleksi Berbasis Kitab Hukum Kanonik 1983. Ejournal. Stkyakobus. Ac.Id, VII (1), 21-40. https://www. ejournal. stkyakobus.ac.id/index.php/jumpa/article/view/119.

Undang-Undang, R. I. (2003). No. 20 tahun 2003 tentang Sistem Pendidikan Nasional. Bandung: Citra Umbara.

Wardani, K. (2010). Peran Guru Dalam Pendidikan Karakter Menurut Konsep Pendidikan Ki Hadjar Dewantara. Proceeding of The 4th International Conference on Teacher Education; Join Conference UPI \&UPSI, 8-10.

Wuryandani, W. (2010). Peranan Keluarga Dalam Menanamkan Nilai Moral Pada Anak Usia Dini. Diklus, 14 (1).

Yulis, M. I., \& Goa, L. (2016). Pendidikan Tinggi Menurut Gravissimum Educationis Dan Relevansinya Terhadap Pengembangan Pendidikan Formal Di Indonesia. SAPAJurnal Kateketik Dan Pastoral, 1 (1), 140-162.

Yunus, H. A. (2016). Telaah Aliran Pendidikan Progresivisme Dan Esensialisme Dalam Perspektif Filsafat Pendidikan. Jurnal Cakrawala Pendas, 2 (1). https://doi.org/10.31949/jcp.v2i1.319 